\title{
The 1976 Economic Report and the Federal Budget: Towards a Long-Run Perspective
}

\author{
KEITH M. CARLSON
}

旅 $\mathrm{N}$ late January, the Administration announced its economic strategy for 1976 and future years. An enunciation of macroeconomic goals along with a prom posed course of policy actions to achieve them is found in three documents - the Federal Budget for Fiscal Year 1977, the Economic Report of the President, and the Annual Report of the Council of Economic Advisers. These three documents present (1) Federal budget plans for the remainder of the current fiscal year and the upcoming fiscal year which begins October 1, 1976, (2) economic forecasts for calendar 1976 and 1977, and (3) a set of economic and budget projections through 1981 which place the more immediate forecasts and policy proposals in a longer-run framework of economic objectives.

The shift of emphasis in macroeconomic analysis and policy to a long-run horizon of six years represents primarily a response to the provisions of the Congressional Budget and Impoundment Control Act of 1974. According to that Act, the beginning of the fiscal year was changed from July 1 to October 1 , but more importantly, this Act required the Administration to make budget projections for a longer-run period than previously. ${ }^{1}$ These budget projections are conditioned by the assumptions that are made about the course of economic activity. It is necessary, therefore, that the Administration's short-run forecasts and policy proposals be consistent with the long-run projections.

With an eye toward long-run economic targets, the Administration has forecast GNP growth of 12.3 percent in 1976, which is distributed as a 6.3 percent increase in real product and a 5.9 percent advance in prices. By comparison, GNP rose 6.5 percent in 1975 , with real product declining 2 percent and prices rising 8.7 percent. Unemployment is projected to average 7.7 percent of the labor force in 1976 , compared to an average of 8.5 percent in $1975 .^{2}$

\footnotetext{
\#ong-run projections were presented in last year's budget as a dry nun, but fiscal 1977 is the first year that they are required under law.

Enployment developments since late January suggest that the economic expansion may be moving ahead of schedule. Unemployment in March was 7.5 percent of the labor force.
}

As a means of implementing the overall economic program, a budget plan is outlined with emphasis on the upcoming fiscal year 1977. As a part of that plan, Federal expenditures (national income accounts basis) are projected to rise 9.4 percent in calendar 1976 and 5.3 percent in 1977. Included among the budget proposals are a number of tax changes which require Congressional action, in addition to those scheduled under existing law. Scheduled and proposed tax changes include; (1) a reduction in tax rates on individual and corporate income on July 1 , 1976, and (2) an increase in social security and unemployment trust fund taxes on January $1,1977$.

The emphasis of the Administration's program is on the Federal budget, yet the CEA Report discusses at some length a course of monetary policy considered consistent with their overall economic program. For the immediate future, the Administration seems content with a monetary policy that stays near the midpoint of the Federal Reserve's then announced target range of 5 to $7 \frac{1}{2}$ percent growth (from third quarter 1975 to third quarter 1976$)$ in the money stock $\left(M_{1}\right){ }^{4}$ What seems as important from the viewpoint of the Administration as the specific rate of increase of money is the extent of fluctuation about the target growth rate. The CEA makes a case for steadiness in monetary and fiscal policy as a means of promoting a sustainable recovery. ${ }^{\text {. }}$

The primary purpose of this article is to summarize and evaluate the economic program as presented in the 1976 Economic Report and the Fiscal 1977 Budget. The focus of the discussion is on the nature of the program as it relates to the achievement of fullemployment with relative price stability. Many nonstabilization issues are also included in the economic program of the Administration, but they are not discussed here.

${ }^{3}$ A more complete listing of proposed tax changes is found in the section entitled "Proposals and Guidelines for Macroeconomic Policy."

4'The takget range for $M_{1}$ has subsequently been widened to $41 / 2$ to $73 / 2$ percent for the year ending fourth quarter 1976.

$\$ 1976$ CEA Report, pp. 20-21. 


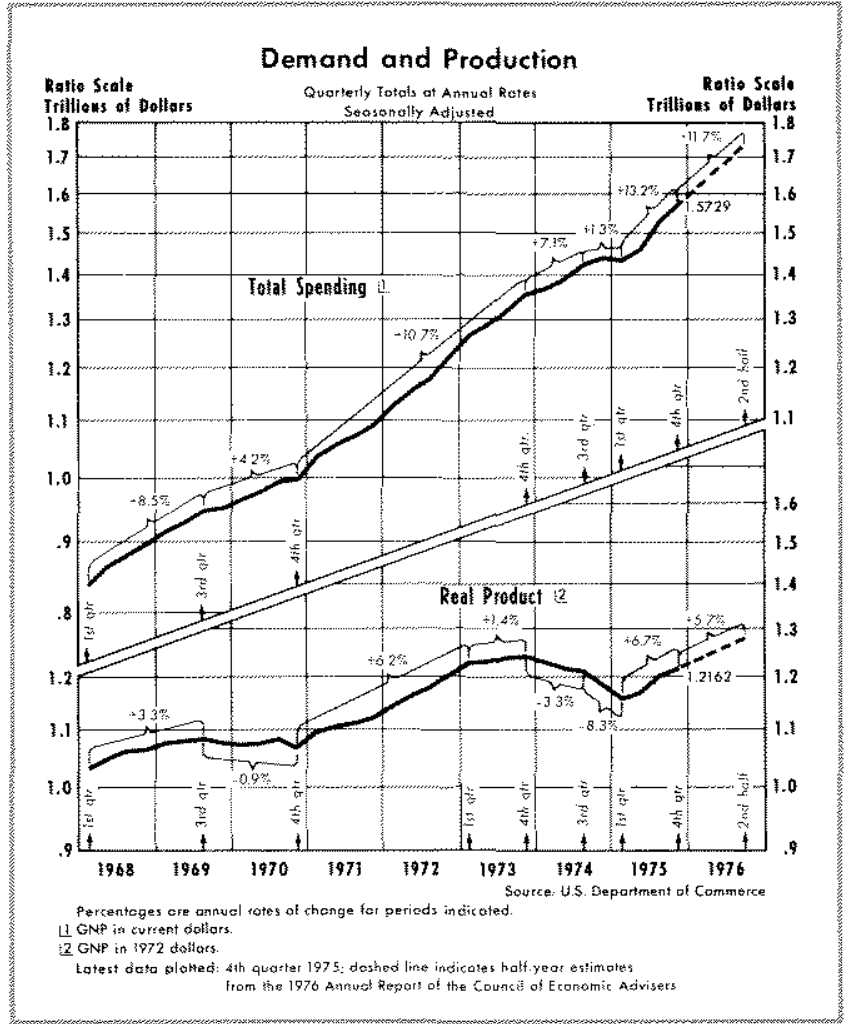

A secondary purpose is to review the CEA's 1975 economic projections in light of the actual course of the economy last year. This review shows where and why the CEA projections went awry. The accuracy of past projections provides some basis for judging how accurate their most recent projections are likely to be.

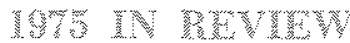

A year ago, when the CEA presented its forecast for calendar 1975, the economy was in the midst of a severe recession, with unemployment rising, output declining sharply, and the deficit in the Federal budget increasing. Furthermore, energy considerations were creating considerable uncertainty with regard to prospective economic conditions. Actually the recession had begun in late 1973, and the economy was showing signs of recovery during 1974, but then output was jolted downward again in late 1974. The CEA's forecast for 1975 , which was very much in line with the consensus at that time, was a realistic one in the sense that it did not project a rosy picture for unemployment and prices.

Against the backdrop of recession and continuing inflation, the Administration presented a very ambitious program of fiscal action. This program consisted of a proposed 15.5 percent increase in expenditures and a number of tax changes which added up to a net tax cut of about $\$ 20$ billion. The Administration also recommended that monetary policy provide "growth in money and credit ... which . . w will encourage a freer flow of credit and lower interest rates. ."

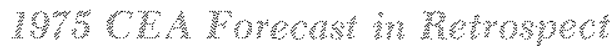

The 1975 CEA Report forecast an increase in GNP of 7.3 percent for the year. Preliminary data indicate that GNP actually rose 6.5 percent. Even though GNP growth was overestimated, the forecast was well within the range of error based on past CEA experience (see Table I), ${ }^{7}$ More significantly the contours of the economic recovery in 1975 were accurately forecast by the CEA, with a recovery beginning before midyear. In fact, the recovery appears to have begun in April or May.

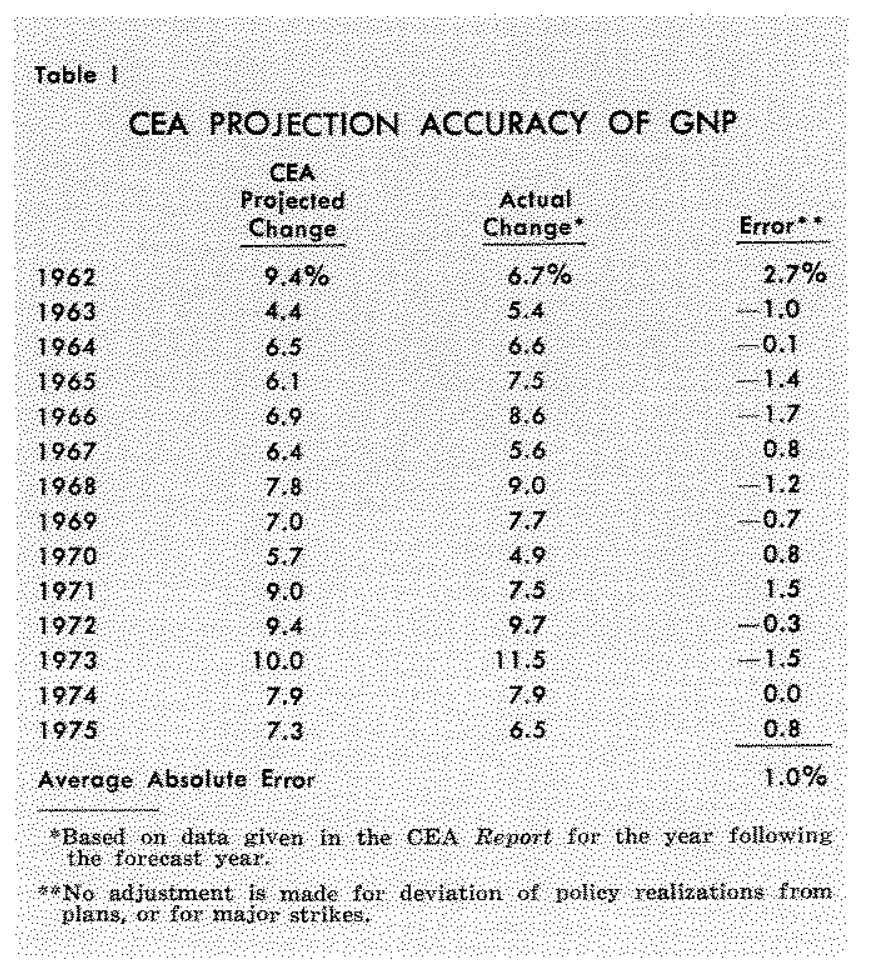

Despite the fact that the CEA's GNP forecast was reasonably accurate, an analysis of the components of GNP indicates that the relative success of the forecast received a major boost from an offsetting error for one item - net exports (see Table II). The CEA overestimated the increase in GNP by $\$ 9$ billion, but if they had not underestimated net exports, the forecast error for GNP would have been $\$ 25$ billion. The forecast was made credible because domestic demand for

${ }^{6} 1975$ CEA Report, p. 26.

7Planned and actual figures in Tables I - IV are not strictly comparable because of the extensive revisions of the national income accounts in early 1976 . 


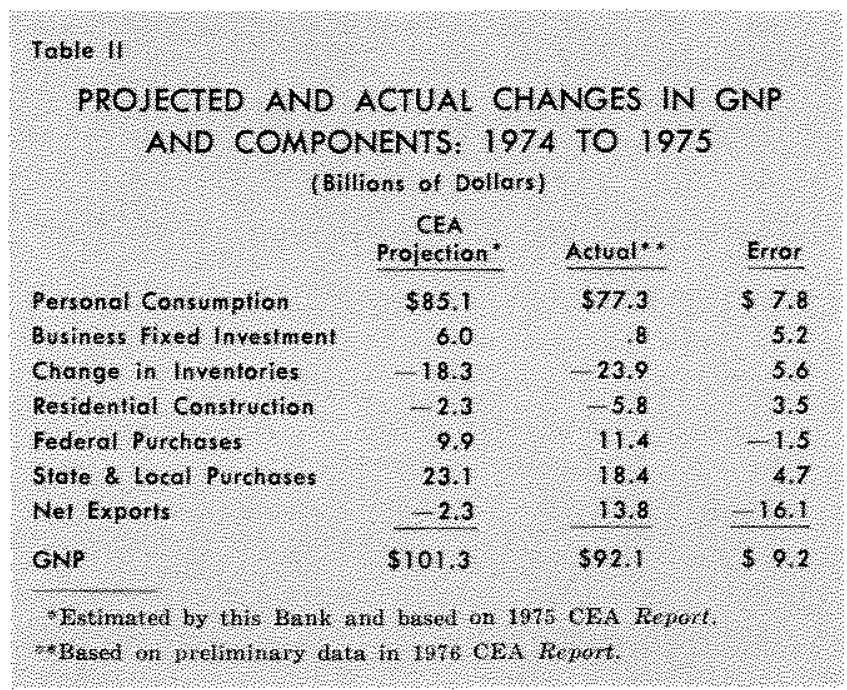

imports was overestimated resulting in an underestimation of net exports. Imports dechined sharply while exports rose slightly.

Examination of the 1975 GNP forecast in terms of its distribution between output and prices reveals another set of offsetting errors (see Table III). The decline in output was actually overestimated with output decreasing 2 percent compared to a forecast decline of 3.3 percent. Similarly, on the inflation side the CEA was also overly pessimistic, projecting an advance of prices of 10.8 percent; prices actually rose 8.7 percent. It should be pointed out, however, that the CEA inflation forecast included projected effects of higher excise taxes on energy products; these proposed excise tax changes were not legislated by Congress. ${ }^{8}$

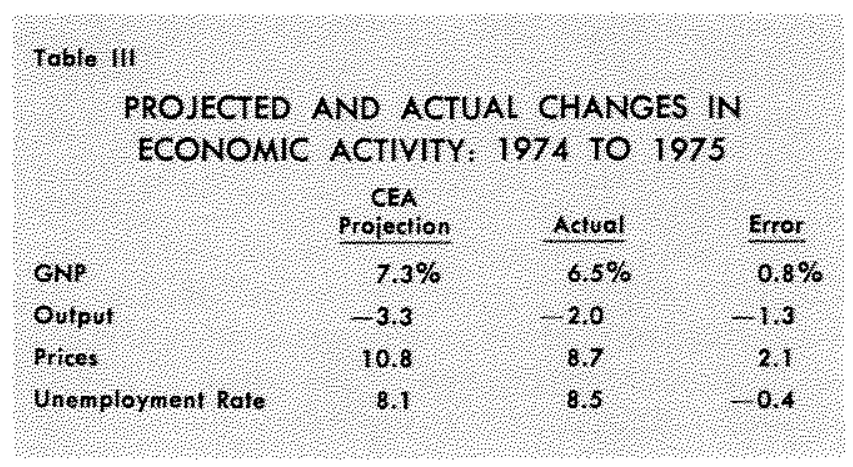

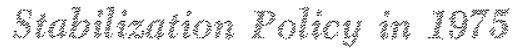

A comparison of observed and forecast GNP is of little meaning in and of itself. In fairness to any forecaster, it is necessary to evaluate the accuracy of the

\footnotetext{
simport fees on crude oil and petroleum products were imposed by Administrative action in 1975, but this action was a very small part of the total energy program that was proposed originally.
}

assumptions that underlie the forecast. Of particular importance for any macroeconomic forecast are assumptions about monetary and fiscal variables. In the case of the 1975 CEA forecast, the planned course of fiscal actions was laid out in great detail, but there was considerable ambiguity as to the prescribed plan for monetary action.

Donetary polmy - The 1975 CEA report was especially vague with regard to its recommendations for monetary policy, and made only very general recommendations :

Monetary policy must be conducted so as to encourage a near term recovery in the economy and a resumption of sustainable economic growth. Toward this end, reasonable growth in money and credit will be required - growth, which, one hopes, will encourage a freer flow of credit and lower interest rates in private credit markets. 9

To assign meaning to this statement it is necessary to recall that monetary growth in the last half of 1974 was slow relative to the trend of the previous $2^{1 / 2}$ years. Although the money stock data have since been revised, at that time the Federal Reserve reported that $\mathrm{M}_{1}$ had grown at only a 2.8 percent annual rate in the second half of 1974 . In early 1975 , most observers translated the CEA call for "reasonable growth" in money as an increase in $M_{1}$ in the 6 to 8 percent range. ${ }^{10}$

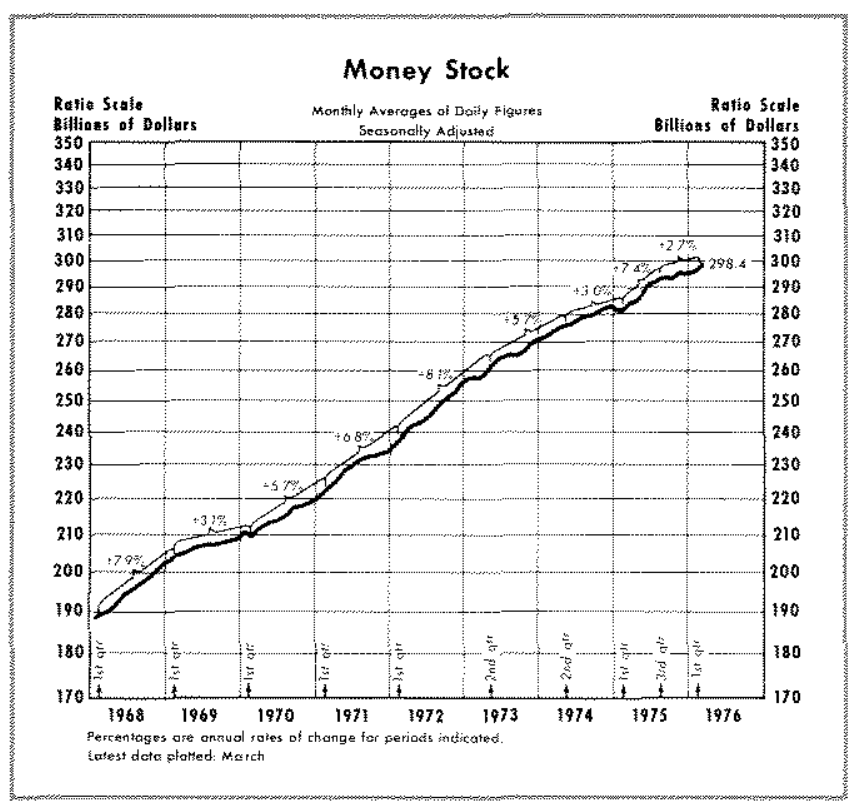

"1975 CEA Report, p. 26.

19See the testimony of David Rowe and Franco Modigliani in The 1975 Economic Report of the President, Hearings before the Joint Economic Committee, Part 2 (February 1975), and Keith M. Carlson, "The 1975 National Economic Program: Another Exercise in Fiscal Activism," this Reviet (March 1975), p. 10. 
Recently revised money data indicate that $M_{1}$ grew 4.4 percent from fourth quarter 1974 to fourth quarter 1975. By this measure, there is little question that monetary actions were less stimulative than the CEA was implicitly assuming in its forecast. Furthermore, the path of monetary actions was an unsteady one; money declined slightly in the first quarter, followed by rapid growth in the second and third quarters, and then finished the year with very slow growth again in the fourth quarter. ${ }^{11}$

Incal folcy - In accordance with tradition, the policy emphasis in the 1975 Report was on fiscal actions. The fiseal plan for calendar 1975 was a very stimulative one, although the extent of net stimulus was overstated if one looked at the projected change in the NIA deficit (see Table IV). The CEA forecast of a large increase in the NIA deficit reflected partly the expected effects of weak economic activity on tax receipts and increased expenditures for unemployment compensation.

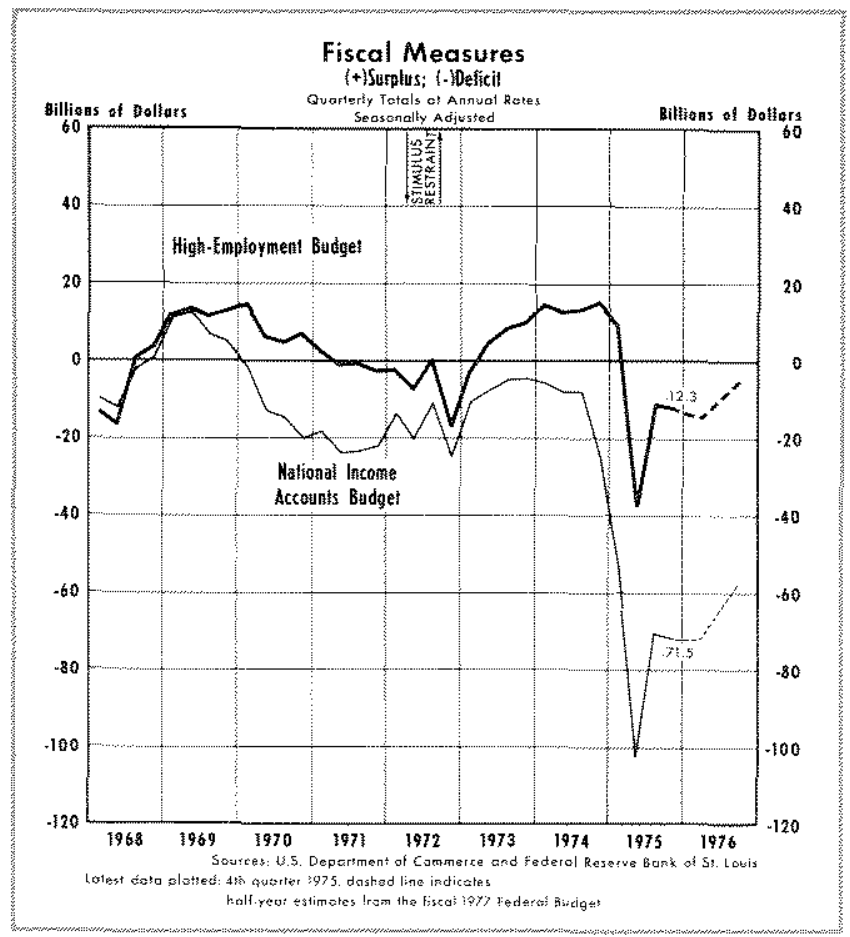

As a measure of fiscal plans, the high-employment budget serves a useful function in helping to isolate the active aspect of the fiscal policy process from the passive response to economic activity. In early 1975, the Administration was planning an increase of $\$ 40$ billion in expenditures on a high-employment basis. Dominating this planned increase were transfer pay-

\footnotetext{
11 For a detaled summary of monetary developments in 1975 , see Nancy Jianakoplos, "The FOMC in 1975: Amouncing Monetary Targets," this Review (March 1976), pp. 8-22.
}

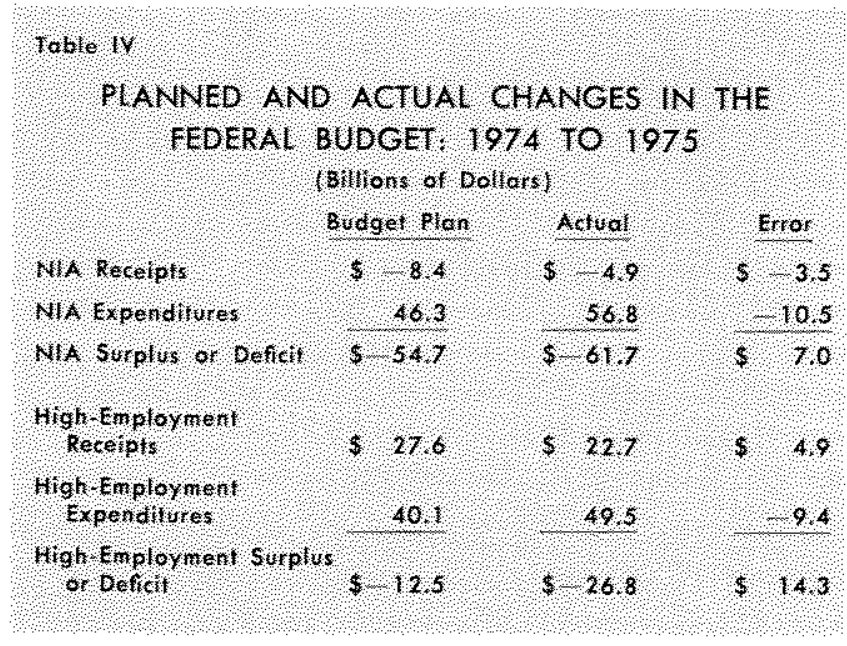

ments which included a one-time payment to social security beneficiaries. The actual increase in Federal spending in 1975 exceeded projections, however, as high-employment expenditures rose by over $\$ 49$ billion, or 17 percent over 1974 .

On the receipts side, Table IV indicates that highemployment receipts increased less than planned in 1975. ${ }^{12}$ The chief reason for this was that the CEA's high inflation forecast was not realized. The growth of high-employment receipts reflects not only changes in tax rates but is also sensitive to changes in the rate of inflation. Congress enacted tax cuts only slightly less in magnitude than those proposed by the Administration in early 1975. The composition of these tax changes, however, was substantially different from that proposed.

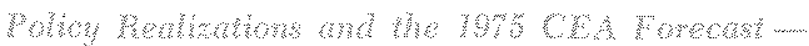
As a result, with tax actions more stimulative than planned (as measured by the change in high-employment receipts), and with expenditures rising faster than anticipated, the net effect of fiscal actions in 1975 was more expansionary than planned. The highemployment budget moved from a $\$ 14$ billion surplus in 1974 to a $\$ 13$ billion deficit in 1975 . This swing of $\$ 27$ billion was about $\$ 14$ billion more than planned. On the other hand, monetary actions were apparently less stimulative than expected. Thus to the extent that policy actions contributed to the overestimate of GNP growth, it appears that monetary actions were primarily responsible. Such a conclusion is highly tentative, however, because the CEA does not give the details of the economic framework that provides the basis for their forecasts.

12The problem of comparability requires emphasis here, because of the rational income accounts revisions by the Department of Commerce and revisions in the high-employ. ment budget by this Bank. 


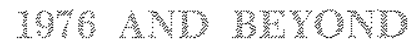

\section{romphre moress}

The economic situation facing the CEA in early 1976 is very much different from what it was a year earlier. The economy is in the midst of a recovery, and the forces of inflation have moderated substantially, Against this backdrop of economic improvement, the CEA has forecast very strong economic growth for both 1976 and 1977. The focus of discussion in the CEA Report is on 1976; very few details are given regarding the 1977 forecast. $^{13}$

A summary of the components of the 1976 GNP forecast reveals that the strength of economic activity is expected to be broadly based (see Table V). Both personal consumption and business fixed investment are projected to rise in the neighborhood of 11 percent. Residential construction is forecast to advance by almost 40 percent from a depressed level in 1975 and inventories are projected to swing from net liquidation in 1975 to accumulation in 1976. Net exports are expected to remain positive, but not at the extraordinarily high rate of 1975 ; this is mainly because economic expansion in the U.S. is expected to increase the demand for imports.

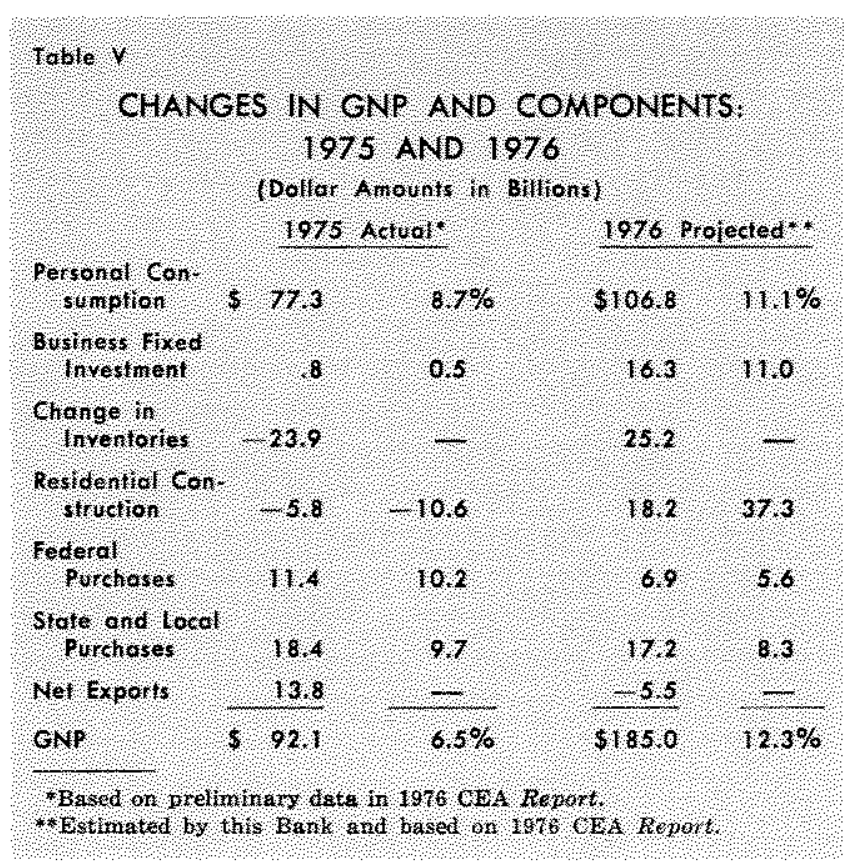

Another facet of the 1976 forecast that stands in marked contrast to the actual experience in 1975 is the projected trend of government purchases of goods and services. Growth of Federal purchases is planned

13The 1977 forecast is found in The Budget of the United States Government, Fiscal year 1977, p. 25, and is not discussed in the CEA Report. to slow relative to 1975 , and once allowance is made for price increases, the 5.6 percent increase in nominal terms translates into little or no change in real terms. State and local purchases are also expected to increase less rapidly than in 1975, although the slowdown is less dramatic than for Federal spending.

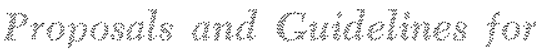 \\ Macroconomic Poluy}

The Administration's projection of considerable economic strength raises questions about the policy assumptions that underlie the forecasts. When viewed in conjunction with the strong economic projections, the Federal budget program becomes a matter of substantial interest because it reflects a proposed move toward less stimulus, at least according to conventional definitions.

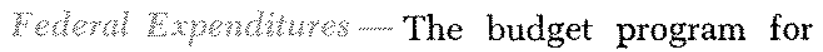
calendar 1976 calls for an increase in expenditures (NIA basis) of $\$ 34$ billion, or 9.4 percent (see Table VI). This projected increase contrasts with the 19 percent increase in 1975. Projections for calendar 1977 indicate further slowing in Federal spending, to a 5.3 percent rate of increase. This pattern of slower growth represents a conscious effort on the part of the Administration to arrest the growth of Government and seek an enlarged role for decision-making by the private sector.

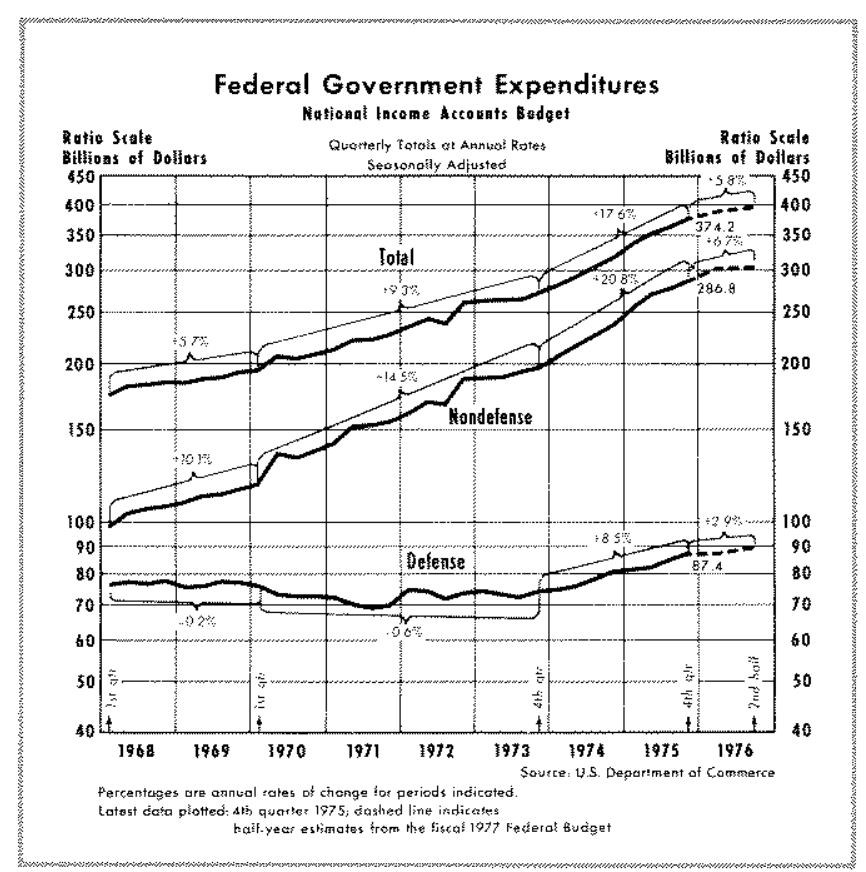

Defense expenditures are projected to increase 5.2 percent in 1976 and 6.3 percent in 1977 . These projected increases reflect planned purchases of sophis- 
ticated military equipment and, given the inflation projections, would represent little change in real terms.

The nondefense category of Federal spending is planned to bear the brunt of Administration cutbacks. After rising at a 15 percent average annual rate from 1969 to 1974 , and accelerating to a 23 percent increase in 1975, nondefense spending is being proposed to increase by a more moderate 11 percent in 1976 . The projected rise for 1977 is 5 percent. Transfer pay ments are estimated to increase 9.5 percent in 1976 and 5 percent in 1977 , rates substantially below the 27 percent advance in 1975 and the 23 percent increase in 1974.

Wesclus - Reflecting an expectation of strong recovery, the Administration sees Federal receipts rising by $\$ 43.5$ billion in 1976 , or 15.4 percent. Receipts would rise even more with current tax schedules, but further tax cuts are being proposed. The Revenue Adjustment Act, which was passed in December 1975, extended the ongoing provisions of the Tax Reduction Act of 1975 , but the extension is only through June 30 , 1976. ${ }^{14}$ The Administration is proposing that taxes be cut by even more than provided by the Revenue Adjustment Act. However, as emphasized in the President's budget message, these cuts are being proposed contingent upon favorable action on the expenditure program.

The tax changes proposed to be effective July 1 , 1976 consist of the following: (1) an increase in the personal exemption from $\$ 750$ to $\$ 1000$, (2) substitution of a flat $\$ 2500$ standard deduction for the current low income allowance and percentage standard deduction; (3) a reduction in marginal tax rates for the individual income tax; (4) a reduction in the maximum corporate tax rate from 48 to 46 percent; and (5) legislation to provide tax relief to electric utilities. ${ }^{15}$ Also, the Administration proposes that the increase in the investment tax credit under the Revenue Adjustment Act be made permanent. The only tax increase for 1976, which is the result of past legislation, is an increase in the base for social security contributions from $\$ 14,100$ to $\$ 15,300$ effective January $1,1976$.

\footnotetext{
14 Most of the provisions (the major exception was the tax rebate) of the Tax Reduction Act were extended, although there were some changes. In particular, with respect to the individual income tax the minimum standard deduction was raised and the tax credit per exemption was increased.

$1{ }^{2}$ There are several other proposed tax changes with a total revemue impact of about $\$ 1$ billion on an annual rate basis (1) a tax credit to encourage financial institutions to hold residential mortcages, (2) accelerated depreciation on plant and equipment investment in areas of high unemployment,

(3) tax deferral for funds invested in stock purchase plans.
}

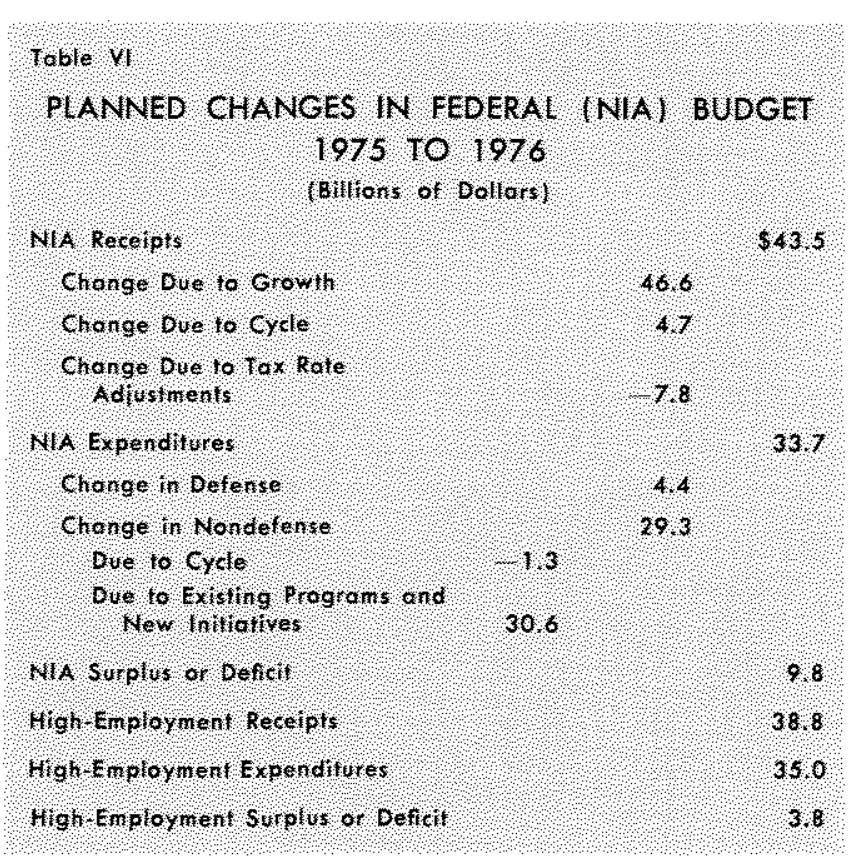

Table VI shows that tax rate changes, as proposed by the Administration or due to past legislation, amount to about $\$ 7.8$ billion in calendar 1976. This estimate reflects the dollar amount of tax changes relative to the rate structure that was in effect, on average, in 1975. Consequently, the $\$ 7.8$ billion amount includes not only Administration proposals but the delayed effects of the Tax Reduction Act (for example, the tax credit per exemption) and the increase in the social security tax base on January 1 , 1976.

Swmos Down powtion - Because of the forecast of strong economic activity and the proposed slowing in expenditure growth, the NIA deficit is expected to be reduced. The $\$ 9.8$ billion decline in the NIA deficit (a decline in the deficit is shown as a positive number in Table VI) reflects a movement in the deficit from $\$ 74.2$ billion in calendar 1975 to $\$ 64.4$ billion in 1976. The effect of the overall budget program on the deficit becomes more substantial by 1977 . Given the budget program and the assumptions about economic activity, the NIA deficit is projected to decline to $\$ 30.7$ billion in calendar 1977 .

With the budget being influenced in considerable measure by the strong recovery, the movement in the NIA budget gives a misleading picture of the extent of fiscal restraint. The high-employment budget adjusts the NIA budget for these feedbacks of economic activity on the surplus or deficit. As a result, as indicated by the $\$ 3.8$ billion reduction in the high-employment deficit, (see Table VI), the economic impact of the budget program in 1976 is one of slight re- 
straint. The budget program is scheduled to show significant restraint in calendar 1977 when it is projected to move to a $\$ 16$ billion surplus, or a swing of $\$ 25$ billion toward restraint.

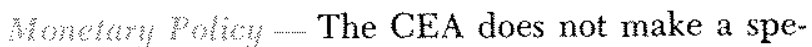
cific recommendation for monetary policy in 1976, but suggests some guidelines along with acceptance, in principle, of the Federal Reserve's target ranges for monetary aggregates.

It is not possible to say with any assurance what growth rates of money are necessary to allow real GNP to grow by $6-6 \%$ percent from 1975 to 1976 . Setting an upper limit on the growth rate, however, should reduce the prospects for a rekindling of inflation. At the same time, the lower limit provides assurance of continued growth in the money supply if the recovery should turn out to be much weaker than expected. 18

As general guidelines for future years, the CEA provides what appears to be a mixed view. On the one hand, they say "the targets must be administered with flexibility," but, on the other hand, they state that "what is called for . . . is a steadier course in macroeconomic policies than has been followed in the past." Reconcliation of these two statements seems to imply a compromise between a monetary rule and fully discretionary policy. The CEA does get very specific, however, in stressing the dangers of moving to the top of the target range:

. . concern with the achievement of greater economic stability in future years suggests that any rate of growth in money which is at the upper limit of the tolerance range announced by the Federal Reserve ( $71 / 2$ percent for $\mathrm{M}_{1}$, 10/2 percent for $\mathrm{M}_{2}$ ), could not be maintained indefinitely if progress toward lower inflation rates is to continue. ${ }^{18}$

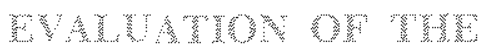

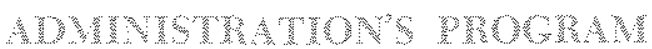

The two primary objectives of the Administration's program are long-run in scope. The first objective is promoting a moderate and sustainable recovery, and the second is checking the expanding role of Government. Although it runs against Keynesian economic doctrine the Administration feels that these two objectives are compatible with one another. These two objectives provide the basis for an evaluation of the Administration's economic program over the six-year horizon, 1976-81.

161976 CEA Report, p. 39.

17 Ibid., pp. 21, 39.

181 bid., pp. $21-22$.

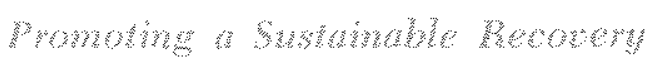

With the U.S. economy in an apparently strong state of recovery, the CEA is concerned with keeping it going, and keeping it going for a long period of time. The desirability of a sustainable expansion is indisputable, but two questions present themselves: (1) is the Administration's growth path for GNP consistent with the policies they propose, and (2) given the GNP growth path, is the price-output scenario likely?

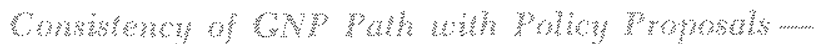
The Administration has presented projections of GNP showing an average annual rate of growth of 12.2 percent from 1975 to 1979 , followed by a 10 percent average rate of increase in 1980 and 1981 (see the first column in Table VII). Along with this projection, a set of budget estimates are given - estimates based on the assumption that real Government services will be maintained at levels implied in the fiscal 1977 budget. In other words, the budget estimates do not represent a projection of prospective fiscal actions but show only an extrapolation of "current services." For this reason, the budget projections should not be interpreted as a set of fiscal actions designed to achieve the assumed path for GNP.

To gain possible insight into the means of achieving GNP growth of 12 percent through 1979, it is interesting to develop conjectures about the course of monetary actions. The Administration provides no information about the pattern of monetary action that they view as necessary to attain their GNP target. The closest they come to committing themselves on this question is their concern about the inflationary potential of sustaining a rate of $\mathrm{M}_{1}$ growth at the top of the Federal Reserve's target range, that is, at 7.5 percent. Quite clearly then, a monetary growth rate of less than 7.5 percent underlies their long-term GNP projection.

Consider the implications of assuming that money grows at a steady 6 percent growth rate through 1981 (shown as Alternative $\mathrm{A}$ in Table VII). Given the Administration's GNP growth path, velocity would have to increase at a 6 percent average annual rate from 1975 to 1979 and a 4 percent rate in 1980 and 1981. Is such a pattern of velocity growth consistent with historical experience?

Examination of rates of change of velocity for the postwar period from 1947 to 1975 reveals that the highest 4-year growth of velocity is 7.4 percent, which occurred from 1947 to 1951 . The second highest period 


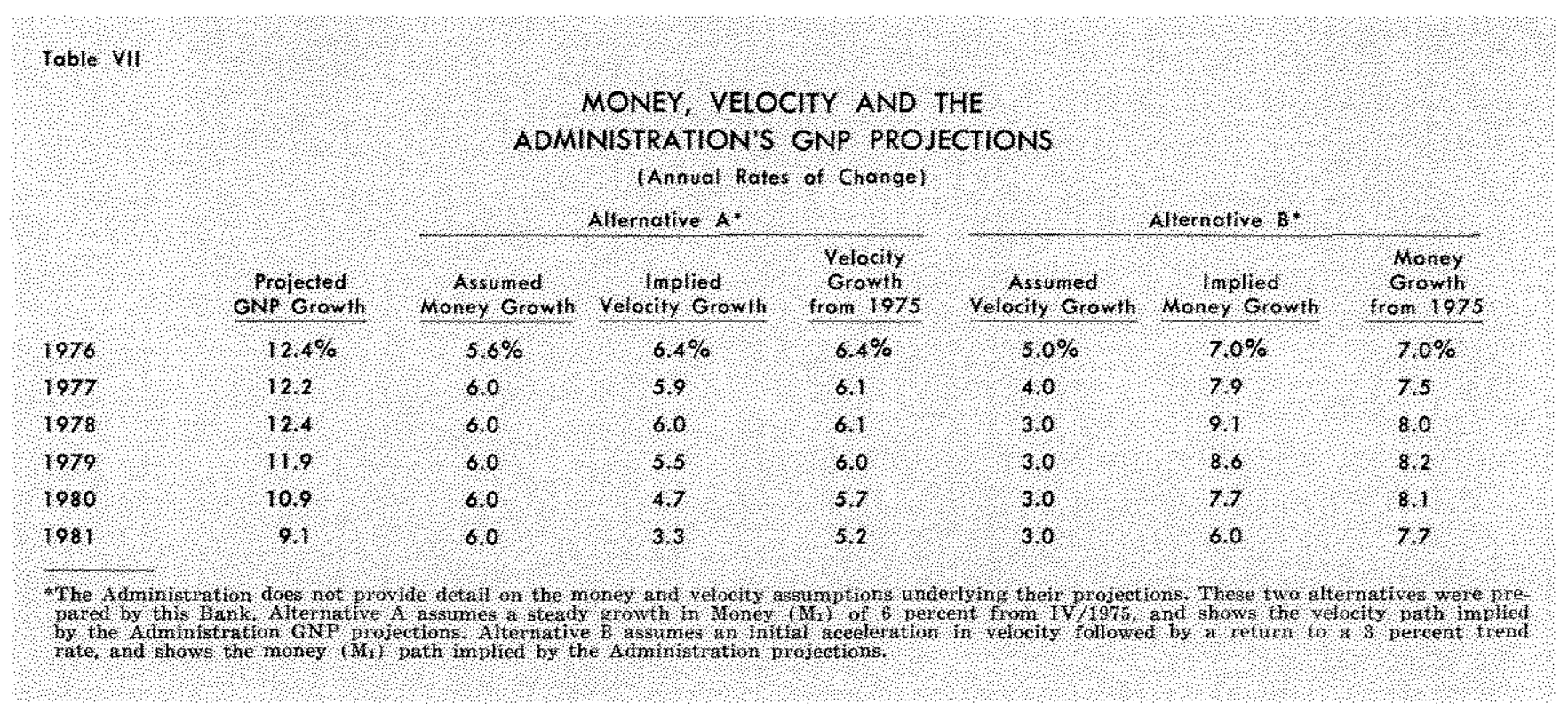

for velocity growth (which overlaps the 1947-57 period) is 1949 to 1953 when it grew at a 5.3 percent average rate. Once we move away from these warrelated periods the highest rate of growth is 3.9 percent from 1958 to 1962.

Another way of analyzing the GNP projection is to assume a path of velocity consistent with past experience, and calculate the implied money path. The result of such a calculation is shown as Alternative B in Table VII, and shows money growth of 8.2 percent from 1975 to 1981 . Whether we focus on the 4-year period from 1975 to 1979 or the full 6-year period, the implied rate of money growth moves above the high end of the Federal Reserve's target range.

Historical experience does not provide an immutable law, but one is forced to question a set of projections that is so much at variance with historical experience. Does the CEA provide any explanation for this newly evolving phenomenon?

Although not directed at the long-term projections, the CEA does devote a section to the discussion of recent trends in velocity. ${ }^{19}$ Listed are a set of factors that have recently come into play tending to increase velocity via downward shifts in the demand for money. Included are references to recent financial innovations and changing regulations relating to telephonic transfer of funds and corporate holdings of saving accounts at commercial banks. Ceteris paribus, there is little question that these innovations increase velocity. The relevant point for the long-run projections, however, is whether these fnancial changes im-

${ }^{19} \mathrm{Ibid}$, pp. 35-39. ply a sustained change in the rate of change of velocity. For velocity growth to step up and be maintained at 6 percent suggests the continuing rapid development of financial innovations into the future. Indeed, such changes are occurring all the time, and the observed rise in velocity in the postwar period attests to the effects of such changes. Pointing to recent factors tending to increase velocity, however, does not imply that such factors will produce a sustained change in the rate of velocity growth.

I questionable possibility of achieving an average growth of GNP of 12 percent over the next four years, it is still of interest to examine the distribution of such growth between price and output change. The Administration's long-term projections show a 6 percent average rate of real growth from 1975 through 1981 (see Table VIII). Furthermore, this rapid advance of output is accompanied by a slowing of inflation from 6.5 percent in 1975 to 4 percent by 1981 .

Table VIII provides a summary of the postwar period showing the growth of output and associated changes in the inflation rate. First of all, there is no period of sustained expansion as long and strong as the one projected by the Administration. Second, there is only one of the four periods of six-year economic expansion that inflation decelerated - the 1955 to 1961 period, which was one of real growth below trend. In general, the more rapid the rate of real growth the greater the acceleration of inflation. It is difficult to draw any definite conclusions with the sketchy data available, but what evidence there is suggests that 6 percent growth of output over a 


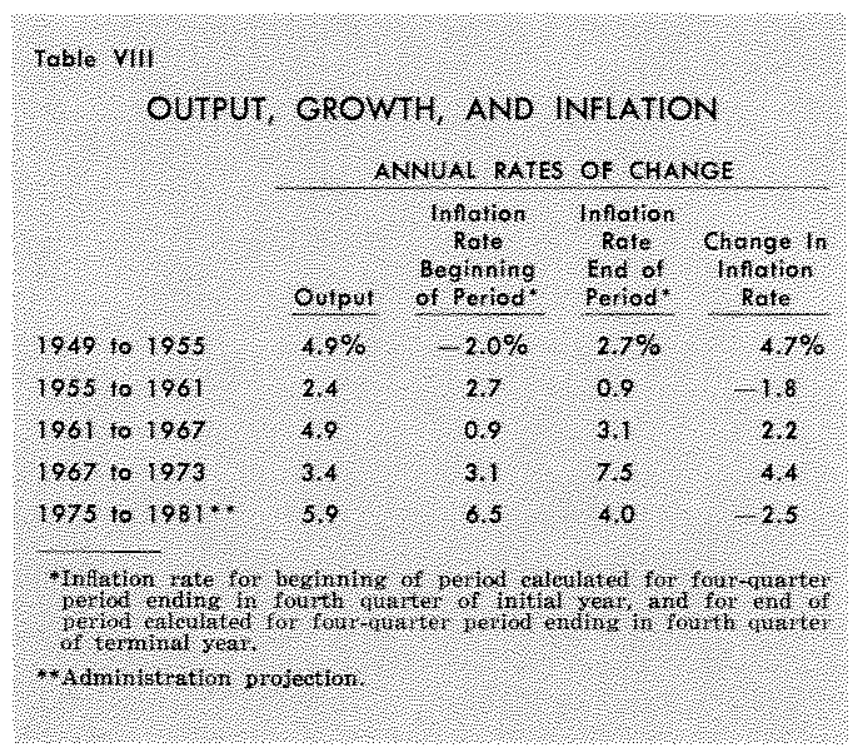

six-year period cannot be achieved without some acceleration of inflation. ${ }^{20}$

In summary, the prospects for sustained economic expansion are good, if monetary growth is held steady - a point which is emphasized by the CEA in their Report. But the growth of GNP is not likely to be as rapid as they indicate unless the rate of monetary expansion is accelerated. Furthermore, even if their path of GNP growth is achieved, there is some evidence from past experience questioning the likelihood of sustaining a rapid growth in output without accelerating the rate of inflation. The latter conclusion is grounded on a weaker foundation, however, because the current situation appears to be unique relative to past experience because of relatively large excess capacity. But when account is taken of the effect of Government regulations relating to product reliability, occupational and consumer safety, and environmental control, the amount of excess capacity currently is much less than a superficial reading of the numbers would suggest.

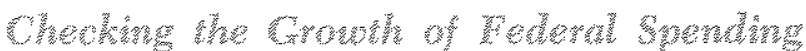

The second major objective of the Administration's program is checking the growth of Federal spending. Questions might arise as to political feasibility, but

\footnotetext{
${ }^{20} \mathrm{~A}$ more complete analysis of the price-output scenario should probably also take the growth of money into consideration. Research at this Bank indicates that a maintained growth in money of 6 percent would produce an inflation rate of be tween 5 and 6 percent by 1981 . See Leonall C. Andersen and Denis S. Kamosky, "The Appopoprate Time Frame for Controlling Monetary Aggregates: The St. Louis Evidence," Controlling Monetary Aggregates $I I$ : The Implementation (Proceedings of a Conference Held at Melvin Village, New Hampshire, sponsored by the Federal Reserve Bank of Boston, September 1972), pp. 147-177.
}

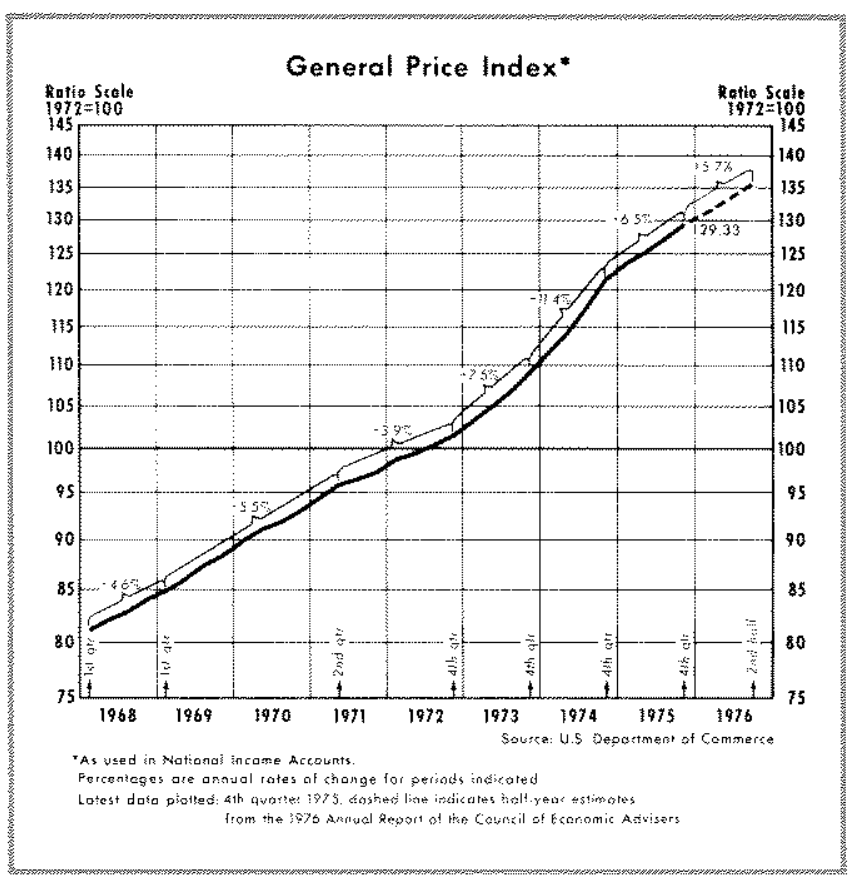

they will not be discussed here. Of concem are the implications of such a goal for the course of the economy in future years.

The CEA offers a challenge to conventional macroeconomics. Virtually all of the well-known econometric models suggest that increased Government spending is stimulative, but this is a feature which applies to the short rum. ${ }^{21}$ In particular, when the economy is operating below some so-called full employment level, an increase in Govemment spending stimulates output and employment, and once full employment is reached, any further increases in Federal spending puts upward pressures on prices. This is the message of Keynesian economics.

The Administration questions the assumption that the Federal government can promote economic expansion for a very long period. The focus in the Report is on the detrimental effects of rapidly rising Government spending on economic growth. The budget program is grounded on the hypothesis that the growth of productive potential will be greater if the size of the Government sector is reduced relative to the private sector.

The financing of Government programs has to come ultimately from incomes and profits generated by the private sector. If the growth of Government is allowed to continue unchecked, financing requirements will

\footnotetext{
"25ee Gary Fromm and Lawrence Klein, "A Comparison of Eleven Econometric Models of the United States," American Economic Retiew (May 1973), pp. 385-93.
} 
eventually work toward discouragement of incentives to work, produce and invest.:2 These are the ingredients that are vital to the growth process.

Even though the CEA does not develop statistical evidence in support of their position, their proposal is a refreshing one because it reflects a long-run perspective that has long been missing from the policymaking process. Recognition of short vs. long-run effects of expanding Government programs represents a significant departure from conventional thinking, which has been dominated by considerations of the short-run transitory effect of fiscal actions on economic activity.

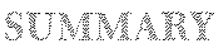

The Administration is in the position of being able to take a long-run perspective now that the recovery seems to be well underway. As a result, they have formulated a budget program that, if enacted, would reverse the trend of Government spending. Furthermore, such a reversal of trend is regarded by the Administration as being consistent with promoting a moderate and sustainable recovery.

The CEA forecasts for 1976 and 1977 are at the high end of the range of the consensus forecasts, indicating a relatively rapid advance of output and continuing inflation in the range of 5 to 6 percent. The scenario for the years following 1977 is somewhat of a mystery, however, as the CEA does not spell out its policy strategy. Furthermore, it is not clear how output could continue to advance rapidly and inflation could abate at the same time.

22. For some discussion of this hypothesis, see Keith M. Carlson and Roger W. Spencer, "Crowding Out and Its Critics," this Review (December 1975), p. 16.
Evidence was presented indicating that the Administration's long-run GNP path is rather unlikely, given past relationships. In particular, even if a relatively rapid 6 percent rate of monetary expansion were asm sumed, the implied pattern of velocity change in the Administration's projections is so far from historical experience that it is difficult to accept. No evidence is developed in the CEA Report supporting a marked and sustained change in the rate of change of velocity.

One of the most interesting aspects of the Report is the recommendation for slowing the growth of Federal spending, and that the long-term interest of the econony will be best served by such a slowing. Despite the significance of the recommendation, the rhetoric is not backed by any quantitative evidence. The proposal is laudable, however, because the focus is shifted from short-run aggregate demand considerations to long-run effects on aggregate supply.

Contrary to many of the past CEA reports, shortrum problems do not seem to be paramount. It is true that the ultimate economic goals have not been achieved nor is it likely that they will be reached in the next year or two. Yet, the foundation for their ultimate achievement rests on the development of policies that aim for steadiness in monetary growth and reducing the size of Government. Policymakers and the public seem to have accepted the fact that achievement of full employment with price stability is not possible within a short period of time, and any attempt to do so is self-defeating. Consequently, the time is ripe to take a longrun perspective and attempt to define a long-term policy strategy. The Administration has succeeded in shifting the emphasis, but the details of the scenario still need to be spelled out.

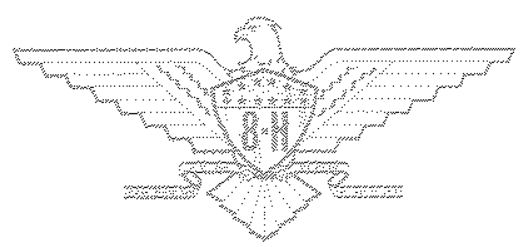

